\title{
La Celestina como emblema del exilio republicano en México: la versión de Álvaro Custodio
}

\author{
Juan Pablo Heras González \\ Universidad Complutense de Madrid
}

\begin{abstract}
Álvaro Custodio (1912-1992) fue uno de los más importantes directores de escena que el exilio republicano de 1939 llevó a América. En su juventud (1932) formó parte de La Barraca, la célebre compañía universitaria que dirigió Federico García Lorca. Al finalizar la Guerra Civil, su militancia comunista, pronto abandonada, le llevó primero a Francia (19391940), República Dominicana (1940-1941) y Cuba (1941-1944), donde empezó a dirigir teatro. Pero fue durante su larga estancia en México (1944-1973), donde logró formar una de las compañías más sólidas del siglo Xx entre las dedicadas al teatro clásico español. Llamada primero Teatro Español de México y luego Teatro Clásico de México, puso en escena con sonoro éxito de público y crítica numerosas obras del Siglo de Oro, además de textos de Lorca y algunos títulos contemporáneos españoles y mexicanos. La obra con la que se inició la trayectoria de la compañía en 1953 fue La Celestina, en versión del propio Álvaro Custodio. El montaje, símbolo del grupo, recorrería toda la república mexicana alcanzando el máximo reconocimiento, hasta que en 1960 se produjo un hecho insólito: la prohibición de su representación en el Distrito Federal, tras una rocambolesca acusación según la cual Custodio habría perpetrado una versión pornográfica, aunque en realidad fuera la misma que la crítica más conservadora había aplaudido los años anteriores. El veto a La Celestina de Custodio en México, tras el que se escondían indudables motivaciones personales, se alargó hasta $1968^{1}$, cuando la recuperó con el respaldo de la Olimpiada cultural. Una vez terminado su exilio mexicano, Custodio llegó a montar otra vez La Celestina en 1978, en Los Ángeles. Hasta su

1.- Nuestras investigaciones (Heras González 2012: 236-242) nos han permitido comprobar que la prohibición se debió exclusivamente a la antipatía del crítico Armando de Maria y Campos (1897-1967), a la sazón asesor de la Oficina de Espectáculos de la capital mexicana, dirigida por un personal tan inepto que en 1960 llegó a convocar al propio Fernando de Rojas para que diera explicaciones sobre lo escandaloso de su lenguaje (Reyes de la Maza 1984: 116).
\end{abstract}


muerte en El Escorial en 1992, La Celestina sería para él un símbolo de su forma de entender el teatro. En este artículo pretendemos explorar las razones por las que un exiliado republicano decide iniciar su más ambicioso proyecto artístico con la obra de Fernando de Rojas, y tratar de definir su poética particular como adaptador, a partir de la más importante de las versiones de La Celestina representadas en México durante el siglo XX. ${ }^{2}$

\section{Lectura insólita de La Celestina}

Cuando se hace balance de las distintas versiones escénicas de $\mathrm{La} \mathrm{Ce}$ lestina que han pisado tablas a lo largo del siglo xx, a la de Custodio se la suele alinear entre las más fieles o «respetuosas» al modelo. Por ejemplo, Joseph T. Snow (1997: 205) la agrupa junto a las de Alejandro Casona, Camilo José Cela o Gonzalo Torrente Ballester, frente a las más libres de Paul Achard, Alfonso Sastre o Ángel Facio. Peter G. Earle (1955: 49) sostiene que su versión «is a faithful reproduction of the original work, scarcely differing from it except by abridgement»; Mandel (1978: 37) afi ma con alborozo que «in spite of the substantial excisions, Custodio's sensitivity and literary awareness has enabled him to capture the thematic richness of La Celestina while at the same time projecting on stage a unified poetic whole». Por otro lado, María Rosa Lida de Malkiel, que nos acompañará con su minucioso análisis en el nuestro, llega a afirmar que la de Custodio es la adaptación que "abrevia más acertadamente el original» y que es «muy superior a los demás adaptadores en sentido estilístico» (Lida 1970: 244, 280). Esta fidelidad no impidió a Custodio tener presente la concepción del teatro del espectador del siglo xx, y tampoco que la naturaleza dramática de La Celestina (para él, indudable) no implicaba necesariamente que el texto original estuviera pensado para la representación. En efecto, el análisis comparativo de la versión de Custodio con respecto al original rojano revela que jamás tuvo como intención crear una obra original partiendo de los materiales de La Celestina (como hizo, por ejemplo, Alfonso Sastre), sino que se planteó a sí mismo la misión de rescatar para la escena un texto tan adelantado a su tiempo, que, aunque nació para ser leído, contiene la semilla nunca germinada del teatro que pudo ser. Haciendo suyas las palabras de Pedro Henríquez Ureña, "si de La Celestina hubiera podido nacer directamente el gran teatro español, se habría configurado de modo distinto al que tuvo» (Custodio 1953: 275³).

2.- Para más información sobre Álvaro Custodio, puede acudirse a mi tesis doctoral (Heras González, 2012), dirigida en la Universidad Complutense de Madrid por José Paulino Ayuso.

3.- La cita está tomada de Plenitud de España. Estudios de historia de la cultura. El esplendor con el que el erudito dominicano pinta los años de Fernando de Rojas pudo recordarle a Custodio el llorado proyecto de la Segunda República: «La Celestina (1499) se escribió en momento de plenitud, la plenitud juvenil que alcanzó la vida española bajo los Reyes Católicos; es con- 
En la particular lectura que Custodio hace de la historia del teatro español esa posibilidad fue frustrada por la Contrarreforma, que impuso a nuestros genios dramáticos del Siglo de Oro unas limitaciones morales y estéticas de las que se libró a tiempo el desinhibido Fernando de Rojas, y que se oponen a la libertad creativa que, en cambio, disfrutó Shakespeare, a mayor gloria del teatro inglés de su tiempo. Para Custodio, La Celestina se erige en símbolo de la libertad perdida, de la España que pudo ser:

\begin{abstract}
$\mathrm{Al}$ erigirse en paladín del catolicismo petrificado, degeneración de aquella unidad religiosa a fortiori que culminó en los Reyes Católicos después de siglos de perseverante reconquista, inseminó las mentes de sus escritores con la cruzada de la ortodoxia, convirtiéndoles en publicistas del dogma, velis nolis, desde los poetas místicos a los dramáticos. Ni más ni menos que lo que en nuestro siglo hizo Stalin con la literatura soviética y Mao TseTung hace ahora con la China. ¡El tiempo corre como un relapso perseguido por los demonios, pero la humanidad no parece muy sensible a la conversión! Porque España, desde la cúspide de su inmenso poder, vio desarrollarse, a pesar de la extrema calidad de sus publicistas literarios, de su armada invencible y de sus temidos tercios, a los herejes protestantes para que ella cayera en la impotencia y la inanidad, perdiendo sus conquistas y sus colonias, mientras la pequeña y heterodoxa Inglaterra de los tiempos de Shakespeare convirtiose en enorme potencia con un imperio colonial que llegó a superar al de España y, si hoy lo ha perdido en su mayor parte, ha sabido conservar, al menos, su prestigio intelectual, al que España, con su incurable fanatismo, parece haber querido renunciar para siempre (Custodio 1969: 10).
\end{abstract}

Custodio encuentra en la victoria franquista un paralelo histórico con el impulso castrador del Concilio de Trento, y en la represión o expulsión de los intelectuales que estaban renovando la cultura española en el siglo $\mathrm{xx}$, un reflejo del camino cerrado al que se enfrentó el teatro incipiente que se prefiguraba en La Celestina. Por eso, rescatar con la mayor fidelidad posible la valiente y desinhibida propuesta de Rojas para el público contemporáneo es para él una manera de dar continuidad a la causa frustrada de la República en territorio mexicano. Así lo afirma cuando presenta por primera vez su versión al público del Ateneo Republicano de México en 1953:

temporánea de la toma de Granada, del descubrimiento de América. Aquella plenitud, hecha de libertad y abundancia, capaz de exceso, dura hasta Carlos V; después declina» (Henríquez Ureña 2001: 535). 
Esperemos que el futuro teatro de habla hispana siga esta trayectoria cuando termine la transitoriedad política que sofoca a España desde hace tres lustros y que los países de la América española que disfrutan de plena libertad sepan recoger el mensaje de la inmortal Tragicomedia de Calixto y Melibea (Custodio 1953: 275).

Sólo una lectura muy concreta permite entender La Celestina como reivindicación romántica de cierto liberalismo moral. Será esta visión de la Tragicomedia la que va a subyacer en la versión de Custodio, no porque pretenda arrogarle unos valores anacrónicos, sino porque la considera parte de una historia de la heterodoxia y quiere reivindicar la valiosa naturaleza «escéptica» de la que entiende que está dotada, una peculiaridad que le permite, como a toda obra maestra, trascender la "natural evolución de las ideas» (Custodio 1953: 272). Buena prueba de que este es el enfoque de Custodio es la postura que mantiene en su polémica con Segundo Serrano Poncela en 1958 acerca de una pregunta que ha mantenido ocupados a numerosos críticos celestinescos: ¿qué les impide a Calisto y Melibea casarse y legitimar su relación si ambos pertenecen a la misma clase social? ¿Es una debilidad de la obra o es coherente con la intención del autor? En su breve escrito "Sobre el secreto de Melibea» (1958), Custodio responde al artículo "El secreto de Melibea», publicado por Segundo Serrano Poncela en el número anterior de la misma revista, Cuadernos Americanos (Serrano Poncela 1958). Serrano aseguraba (sin citar como precedente a Emilio Orozco, como denuncia Custodio ${ }^{4}$ ) que las causas del secretismo que envuelve la relación entre Calisto y Melibea se encuentran en la naturaleza conversa de la familia de Pleberio, lo que trata de probar acudiendo a diversas citas y rastreando el aire hebraico que se desprende del monólogo final del padre de Celestina. Esta tesis podría incluirse en lo que Dorothy S. Severin llama "escuela judeo-pesimista», que lee el discurso de Pleberio, y por ende La Celestina completa, como «una desolada condena del amor, un concepto pesimista de la vida que deja pocas esperanzas de reforma o de redención de la especie humana", en oposición —o en paralelo, según se mire- al «punto de vista tradicional y moralista" (Severin 37). Para Custodio, en cambio, las dificultades que complican la vida a los amantes pueden explicarse sin necesidad de recurrir a «impedimentos raciales o místicos que ni el autor del primer acto ni Fernando de Rojas, su genial continuador, tomaron en cuenta» (Custodio 1958: 210). Para él, si Calisto se ve obligado a recurrir a la alcahuetería es porque Melibea rechaza su precipitación inicial, y porque la tercería «era uno de los medios más naturales en siglos de encerramiento y de invencibles prejuicios religiosos y sociales» (Custodio 1958: 210). Una vez que

4.- Custodio no lo dice, pero el trabajo que no citó Serrano Poncela es OROZCO, Emilio, «La Celestina: hipótesis para una interpretación», Ínsula, 124 (marzo de 1957), 1, 10. 
Celestina logra ganar para Calisto la voluntad de Melibea, el ardor del impetuoso galán no tendrá ya freno: rotos los límites, "ya no hay ocasión de regularizar esos amores. Los amantes pecaron y lo seguirán haciendo cada noche en el mismo lugar durante un mes entero" (Custodio 1958: 212). Hasta aquí, Custodio utiliza los mismos argumentos de los críticos que entienden La Celestina como una lección moral, como advertencia ante los peligros de las relaciones ilegítimas ${ }^{5}$. Él, en cambio, prefiere extrapolar la apertura moral que atribuye a Fernando de Rojas y su ámbito (al menos en la expresión de las ideas) a la motivación interna de los personajes de la Tragicomedia. Para Custodio, el conflicto es la consecuencia inevitable de que los dos personajes - Melibea con mayor grado de responsabilidad - transgredan las convenciones de su tiempo al asumir una relación que ambos desean pero que la sociedad considera pecaminosa. Las dudas y problemas de conciencia de Melibea serían sólo un débil pero persistente reflejo de prejuicios sociales en un espíritu enamorado que aspira a superarlos. Por eso, la motivación del suicidio de Melibea es clara: «se sabe deshonrada y ha perdido al hombre que ama» (Custodio 1958: 213). Por todo ello, a la Melibea de Custodio, como veremos, se la ha acusado de excesivamente romántica, como consecuencia del hincapié que la adaptación hace en los «invencibles prejuicios religiosos y sociales», de los que Melibea resulta ser víctima. Custodio trasciende así tanto las lecturas moralistas ("de lógica de sacristía», 1958: 210) como las nihilistas, e interpreta el discurso final de Melibea no como lección aprendida de una conducta equivocada, sino como denuncia de un sistema hipócrita y represor. De ahí que en su versión las pequeñas alusiones que van configurando al personaje de Pleberio, incluso antes de que aparezca en escena, vayan en la misma dirección: dibujar la sombra de una ominosa autoridad paterna que fuerza a Melibea a esconder su relación con Calisto. Y sólo el sentimiento de culpa que se impone la joven tras la muerte de su amado le impulsará a confesar el secreto tan celosamente guardado.

En 1968, después de haber sufrido años de prohibición que habían hecho de La Celestina un texto insospechadamente subversivo, cuando a Custodio le corresponde redactar el texto del amplio programa de mano trilingüe (inglés, francés y español) de La Celestina para el «programa cultural de la Olimpiada» de México 68, preferirá ceder la palabra a una firma nada sospechosa, la de Buenaventura Carlos Aribau, que afirmó lo siguiente en una introducción que escribió para La Celestina en la edición de la Biblioteca de Autores Españoles de 1846:

Tenemos que aceptar La Celestina tal como se escribió y se publicó, sin que sea nuestra la culpa de que en su siglo la sociedad tuviese costumbres más licenciosas que

5.- Por ejemplo, Bataillon o Green. Véase un buen ejemplo de esta posición en Alborg 1979: 585-591. 
en el presente, o tal vez menos decoro para ocultarlas (...) La inmoralidad en literatura no consiste en retratar fielmente los vicios de la sociedad, sino en presentarlos bajo un aspecto amable y seductor que estimule el apetito a la torpeza: en vez de descubrir las malas artes para que se precavan los menos advertidos, ofreciendo el amargo fruto de las pasiones o hábitos desordenados, y señalando ya el castigo de la maldad, ya la ignominia de que se cubre ante la pública opinión, ya los consuelos del arrepentimiento y las ventajas de la enmienda. Pocos libros habrá que llenen tan cumplidamente este útil objeto como la Tragicomedia de Calisto y Melibea (Programa de mano de La Celestina para el «Programa cultural de la XIX Olimpiada», 1968).

No es que comparta Custodio plenamente la lectura de Aribau: solamente se sirve de la autoridad que le dan los más de cien años transcurridos para abochornar, por trasnochados, a sus censores y a todos aquellos que, todavía en la década de 1960, encontraban en La Celestina una incitación a la inmoralidad.

Por eso, en un congreso de 1974 Custodio reiterará su punto de vista y arremeterá contra cualquier lectura moralista:

Que Calisto recurra a Celestina (...) es porque no persigue otro fin (...) que la posesión material de Melibea, y para eso sirven precisamente las alcahuetas. ¿Qué debilidad dramática puede hallarse en algo tan evidente como el propósito del autor y el de Calisto desde el comienzo mismo de la Tragicomedia? El manejo por la crítica de prejuicios sociales como presunta debilidad de un texto tan actual concebido en el siglo Xv muestra una vez más la superioridad del genio sobre su propia época en que la obra, pese a su éxito de lectura, tuvo reparos numerosos de índole moralista que todavía no terminan (Custodio 1977: 480).

A pesar de la particularidad de esta lectura, las transformaciones a las que sometió a La Celestina no fueron nunca abusivas. Custodio entendía el respeto al texto original como una forma de recuperar la vitalidad de una obra que para el público del siglo xx resultaba agotadora por su extensión y distante por sus claves retóricas. Como dice Snow, el valor de las adaptaciones teatrales de La Celestina en nuestro tiempo no está en la reconstrucción arqueológica, sino en la búsqueda de la continuidad de sus «temas vitales» (Snow 1997: 205). 


\section{Pistas y motivaciones}

Entre las valoraciones que matizan la enorme admiración que sentía Custodio hacia La Celestina encontramos algunas que permiten entender el porqué de muchas de sus decisiones como adaptador. Veamos:

Adolece La Celestina de una irrefrenable pedantería latinizante, fruto del tiempo. Se escribe en pleno Renacimiento, cuando nobles y plebeyos cultivaban las letras como una moda. Y como la obra está compuesta en 'rudo y desierto romance' según decía Juan de Mena del castellano, ha menester de la lengua culta, el latín, para revestirla ricamente, y de las citas abundantes con las que el autor —o autores- sienten necesidad de mostrar su erudición humanística (Custodio 1953: 266).

Efectivamente, al considerar la frondosidad sentenciosa de La Celestina como una excrecencia derivada de la «moda» del momento, explicable sólo por el afán de erudición de su autor y no por exigencias dramáticas o por enriquecimiento conceptual de la obra, al adaptador no le temblará la tijera a la hora de desbrozar las abundantes citas, más o menos ocultas, de Petrarca y tantos otros humanistas. La necesidad de cortar y reducir el texto de La Celestina parece inevitable y tiene numerosos precedentes, bien conocidos por Custodio, que refiere algunos con detalle en el prólogo de su edición (Custodio 1966: 20-30). Sin embargo, el afán de fidelidad y respeto al original le impulsa a justificar la reducción con argumentos históricos:

Se ha dicho que 16 o 21 actos son demasiados para una obra dramática tal y como concebimos la dimensión teatral desde Lope de Vega. El tiempo y la capacidad de asueto hanse disminuido considerable y lamentablemente desde las gloriosas tetralogías helénicas que a veces se prolongaban en los anfiteatros al aire libre ocho y diez horas. Cuando se escribe La Celestina, el autor -o los autores- no tienen otros puntos de referencia que las comedias latinas o sus torpes imitaciones medievales (Custodio 1953: 268).

Cuando en 1966 Álvaro Custodio publica su versión, desde muy pronto deja claro que "este no es el texto completo de La Celestina, sino un arreglo para llevarla a la escena con una duración no mayor de tres horas. La tragicomedia genial no fue concebida para ser representada, sino leída» (Custodio 1966: 15). Aclaración obvia, si se quiere, pero que nos habla del rigor filológico y pedagógico que distingue a Custodio de otros adaptadores. De hecho, la libertad con la que decide cortar el texto no se 
corresponde con un afán idéntico para el añadido, discreto en comparación con otros adaptadores, quizá porque Custodio quiso seguir el consejo de Moratín que incluyó en el programa de la representación de 1968 a través de la argumentación ya citada de Aribau:

Un hombre inteligente haría desaparecer los defectos de La Celestina sin añadir por su parte una sílaba al texto (Programa de mano para la Olimpiada de 1968). ${ }^{6}$

Sin embargo, el amor de Custodio por La Celestina le llevó a proponer, años más tarde, un montaje del texto íntegro (Custodio 1977: 482-483; Laborda 1974: 89-90) como parte de un Festival Internacional sobre la obra de Fernando de Rojas que se celebraría periódicamente en Toledo. La representación que él soñaba dirigir, a la que se le presuponía una duración de unas siete horas repartidas entre tres días (Ponce 1984: 47), nunca se llevó a cabo 7 .

Hemos expuesto las razones para la reducción textual, para los cortes y para las adiciones que conlleva tal proceso. Pero, ¿es necesario justificar por qué la mayor parte de su versión es repetición casi literal del modelo? No cabe dudar del valor literario de La Celestina, pero, ¿tal cantidad de texto original, en el más puro castellano de finales del siglo Xv, puede funcionar en una representación teatral en el México de mediados del xx? Para Custodio, los valores dramáticos de la obra de Fernando de Rojas y la inteligibilidad de su lenguaje no son menores que los de Shakespeare:

Los arcaísmos y latinismos de La Celestina o las expresiones alusivas a hechos de su tiempo son escasos en obra de tales dimensiones. Su estilo es claro y hermoso, no crea dificultades serias de comprensión ni en su lectura ni durante su representación escénica. El autor o los autores de la Tragicomedia demuestran un dominio intuitivo en el arte del coloquio (primera condición necesaria para su validez dramática) porque la réplica es siempre exacta y consecuente logrando en ocasiones una belleza de expresión sólo inherente a las obras maestras (Custodio 1977: 474).

Y si el estilo es comprensible para el público del siglo Xx, mucho más la disposición de la trama y el ritmo de la acción:

La trama de La Celestina es de una extrema simplicidad, la sucesión de escenas tiene un ritmo casi cinematográ-

6.- Aribau toma la cita de Orígenes del Teatro Español, seguidos de una colección escogida de piezas dramáticas anteriores a Lope de Vega.

7.- En realidad, Custodio recogía un proyecto de Manuel Criado del Val, que ya había propuesto lo mismo al Ayuntamiento de Talavera de la Reina hacia 1967 (Criado del Val 1974). 
fico y ningún personaje se aparta un solo instante de su no muy compleja contextura anímica (...). Basta un sencillo nudo de acción para convencernos de su profundo humanismo —en su sentido prístino—y de la emotiva al par que sabrosa sucesión de situaciones admirablemente encadenadas como podría hacerlo el autor más experto de nuestros días en lo que se refiere a técnica y ritmo (Custodio 1977: 477-478).

Por eso la versión de Custodio se aleja de las refundiciones al uso de tiempos anteriores, o de las interpretaciones libres de sus contemporáneos. El aprecio que algunos eruditos han mostrado por su fidelidad al original está fundado en el respeto y amor al texto con el que Custodio emprende su labor dramatúrgica. Veremos mediante el análisis detenido de su versión si es tan coherente con estos presupuestos como parece a primera vista.

\section{¿Versión o versiones?}

Hoy sólo conservamos el texto de una de las versiones de La Celestina que Álvaro Custodio llevó a escena: la que él mismo editó en 1966. Pero tenemos constancia de que hubo al menos cuatro: la primera, de 1953, estrenada en el Ateneo Español de México; la segunda, de 1957, estrenada en el Teatro del Caballito; la tercera, publicada en 1966, en plena prohibición, y estrenada en 1968 en el Teatro Reforma; la cuarta y última, presentada en 1978 en el Inner City Cultural Center's Lodge Theater en Los Ángeles.

Sólo podemos reconstruir a partir de diversos testimonios las variantes que distinguían a la versión de 1966 de las otras tres. Lo haremos pormenorizadamente cuando nos introduzcamos en el análisis de la que disponemos, pero por ahora podemos adelantar una curiosa tendencia: será en la primera donde más recorte textos y escenas del original, y en la última en la que los recupere en mayor medida, como si el amor que tuvo por este clásico y la confianza que mostró siempre en sus posibilidades dramáticas no hubieran hecho sino dilatarse con el paso del tiempo.

\section{La puesta en escena}

Como era de esperar, no conservamos grabación alguna de los montajes de La Celestina, aunque sí numerosas fotos ${ }^{8}$ de representaciones de

8.- Del montaje de 1953 en la Sala Molière, en la edición de 1966, en un cuadernillo sin paginar situado en el centro del libro (Custodio 1966). En cuanto al de 1968, en el Teatro Re- 
1953 y 1968. Aunque la mayor parte de las decisiones dramatúrgicas de Custodio pueden deducirse del análisis de su versión, trataremos de rastrear, a partir de los testimonios de los que disponemos (con frecuencia del propio director), los datos que nos permitan reconstruir aquellos elementos puramente escénicos que se escapan de la partitura literaria.

La intención didáctica e ilustrativa que caracterizó al primer montaje de La Celestina en 1953 lanzó a Custodio a la búsqueda de un tipo de puesta en escena propio y genuino de la época de Fernando de Rojas. Y como él mismo nos informa en el prólogo a su versión (Custodio 1966: 37), lo encontró en Plenitud de España, un libro de Pedro Henríquez Ureña que le serviría de fuente también para otro tipo de consideraciones:

La Celestina está concebida escénicamente dentro del
antiguo escenario de «decoraciones simultáneas» en que
había tres interiores posibles, detrás de cortinas corredi-
zas, y el espacio delantero, libre, servía para los perso-
najes que atraviesan calles o caminos (...). Dónde haya
visto escenarios de tipo Renacimiento el autor de La Ce-
lestina, no podemos conjeturarlo; tal vez no los vio, pero
debió de tener noticia de ellos, como conocedor que era
de la cultura italiana de su tiempo. La Celestina es una
comedia humanística del tipo de las que se escribían y
representaban en la Italia del siglo Xv (Henríquez Ureña
2001: 535-536).

Este tipo de disposición de la escena, que permitiría a Custodio recrear la sencillez del teatro primitivo y aprovechar a la vez los escasos recursos materiales con los que contaba, fue el elegido para esta primera versión:

Nuestra versión recurrió a este antiguo escenario de decoraciones simultáneas a base de cortinas corredizas. A la derecha del actor estaba la casa de Melibea; en el centro, la de Celestina - y una vez la de Areúsa- y a la izquierda la de Calixto. Cuando las cortinas estaban cerradas, la acción se suponía en la calle. En todo caso, se utilizaba completo el escenario para cada escena. (...) Nuestra concepción escénica, sumamente sobria, tiene todo el carácter de una representación de teatro de cámara (Custodio 1966: 38).

Sólo hace falta ver las fotos que acompañan la edición de 1966, tomadas de las representaciones de la Sala Molière en 1953, para comprobar lo exacto de esta apreciación de Custodio: los actores actuaban frente a los 
propios telones. La sencillez del atrezo no le iba a la zaga, como recuerda Earle en este jugoso recuerdo de la función, en el que nos rescata, además, valiosos datos acerca de la iluminación:

The stage, also, is practically devoid of scenery. Only a bench is utilized until the last scene of the first act, when a simultaneous stage, rear-center, is opened, disclosing Areúsa in bed. In Act II, the same rear stage is opened and a long table used for Celestina's feast is pulled out perpendicularly. In the second part of Act II, during Calixto's first appointment with Melibea, a white «scrim» represents the walls of Pleberio's house (Act XII of the original). When Calixto leaves the lights go out and the scrim is removed for the foilowing scene (Celestina's murder). In Act III, Calixto and Melibea's last rendezvous is decorated only by a large paper moon. No wall or ladder is necessary, as Calixto falls to his death off-stage. When Melibea commits suicide the lights are extinguished again. As Pleberio leans over her corpse and laments her fate, a soft red light is turned on. (Earle 1955: 50).

Sabemos además que en esta primera versión de 1953, y también en la estrenada en 1957 en el teatro del Caballito, la extrema austeridad escenográfica del montaje era compensada, para mejor comprensión del público, con la aparición sucesiva de carteles "con caracteres renacentistas» que bajaban del peine del teatro e indicaban los lugares en los que sucedían los distintos cuadros: "Jardín de Melibea, Casa de Areúsa, Calle, Casa de Celestina, Casa de Calixto...» (Custodio 1966: 38).

Años después, una vez superada la prohibición, la compañía tuvo la oportunidad de ofrecer un montaje más sofisticado. Fue en 1968, en el teatro Reforma. La financiación del IMSS permitió un despliegue de efectos técnicos que transformó por completo el sencillo montaje original de Custodio. Las sobrias telas lisas fueron sustituidas por telones ricamente pintados, mientras que la unión de recursos musicales y escenográficos trataba de sumergir al público en el mundo cuatrocentista de La Celestina. Así lo describe el propio director:

EI TEATRO CLASICO DE MEXICO decidió reponer LA CELESTINA como gran producción, en el escenario un tanto irregular del Teatro Reforma, perteneciente al I.M.S.S., pero cuya curiosa configuración permitía darle un concepto totalmente nuevo, como teatro vivo, sin cortar la continuidad escénica, donde se mezclan el recuerdo del teatro renacentista - no hay telón y todos los cambios de decorado se hacen a la vista del públi- 
co- con los recursos de la técnica moderna para el mejor resultado plástico y sin obligar al público a imaginar lo que el realizador no fue antes capaz de ofrecerle. (...) LA CELESTINA del Teatro Reforma aparece abierta a los ojos del espectador, como un corral de comedias; al comienzo de la tragicomedia, los actores se mezclan con el público, como quien va a cumplir una misión y dos de ellos ofrecen, como en los antiguos corrales, aloja y naranjas a los espectadores. Una voz, la del Retablo de Maese Pedro de Falla, entona la frase consabida. Siéntense todos que comenzamos... Oímos un redoble de tambor y surgen las primeras cadencias de la prosa de Rojas. Son las palabras de Pleberio en su monólogo final: " $\mathrm{O}$ h, mundo de congojas lleno, de miserias acompañado!...». El personaje desaparece y surge el encuentro casual de Calixto y Melibea cuando aquel busca el jerifalte que cayó en el jardín de la doncella... El decorado inicial es la calle de una ciudad del Siglo xv, con sus casas y torres que abarcan una dimensión de casi veinte metros de altura, concebidas en los tonos suaves de los pintores renacentistas (...) reproducidas con maestría por el notable pintor escenógrafo mexicano David Antón. En cada escena desciende, a la vista del público, un telón que nos transporta a la casa de Calixto, otro al jardín de Melibea y en un momento dado suben calles, torres y jardines para mostrarnos el interior, con su piso superior donde huelga una pupila de Celestina con el putañero de turno, mientras abajo, la vieja lava su ropa o repone el virgo perdido de alguna mozuela. Cuando transcurre la acción, aquella casa celestinesca se convierte después en la muy distinta alcoba de la apetitosa y doliente Areúsa, que habrá de aceptar de buen o mal grado la compañía nocturna del libidinoso Pármeno, por intercesión de la proxeneta. (...). En los intermedios el público escucha encantadoras canciones españolas de músicos renacentistas, Mateo Flecha, Juan Arenas... (Notas y Comentarios, 20 , enero-febrero de 1968).

Si las limitaciones materiales del montaje de 1953 obligaron a Custodio a situar fuera de escena las muertes de Calisto y Melibea, la posibilidad de utilizar plataformas y andamios, unida a más complejas técnicas de iluminación, le permitirá subrayar en 1968 estos momentos álgidos de la Tragicomedia con efectos sumamente espectaculares: 
En el Acto Tercero se utiliza, en forma inesperada, la plataforma superior, donde primero aparece Calixto, anticipando su ulterior caída de la escala y después, muerto el mancebo, Melibea, que sube hasta una torre, casi en el techo del teatro, desde donde explica a su padre su resolución de despeñarse para seguir a su amante: el efecto del suicidio es tan impresionante que el público recibe la sensación - por medio de un simple recurso de iluminación y del doblaje de la figura - de la caída de la joven. (Notas y Comentarios, 20, enero-febrero de 1968).

En efecto, la austeridad del primer montaje obedecía más a las dificultades materiales de la joven compañía que a una decisión puramente artística. La habilidad de Custodio hizo de la necesidad virtud y de la pobreza una reivindicación del escenario renacentista, lo que no le impidió reconocer, aunque fuera para justificar los oropeles del nuevo montaje, que el de los años 50 resultaba insuficiente, «magro» (Notas y Comentarios, 20), para La Celestina que aspiraba a mostrar al público mexicano. Custodio afirmó que la versión de 1968 fue la mejor de todas las que puso en escena en cuanto a las condiciones del montaje. Sin embargo, reconocía que el reparto no podía superar al de 1953: aquellos que entonces comenzaban su carrera, como Ofelia Guilmáin o Ignacio López Tarso, eran ya en 1968 actores muy reconocidos y solicitados en el cine y la televisión, de modo que Custodio no pudo contar con ellos; por otro lado, una salud precaria impidió a la mítica actriz del exilio Amparo Villegas reencarnarse de nuevo en Celestina?.

Custodio no guardó tan grato recuerdo de la tercera de sus Celestinas, la presentada en Los Ángeles en 1978. Se trataba esta vez de una Celestina políglota, curiosa propuesta de la Bilingual Foundation of the Arts ${ }^{10}$. Durante los fines de semana de octubre y noviembre de 1978, en el teatro del Inner City Cultural Center el público angelino pudo disfrutar de funciones alternas en español y en inglés ${ }^{11}$. Buena parte del reparto de ambas versiones dominaba las dos lenguas y actuaba en todas las funciones; el resto cambiaba, de modo que algunos personajes, como Calisto, Sempronio o Areúsa, eran interpretados siempre por los mismos actores, y otros, como Celestina, Melibea o Pármeno, cambiaban de piel según cuál fuera la lengua de cada representación, con la variabilidad en la interpretación y

9.- Amparo Villegas (1890-1969) representó a Celestina en todos los montajes de Custodio entre 1953 y 1960. Era hija de Francisco Fernández de Villegas, Zeda, cuya versión de La Celestina se representó en el Teatro Español de Madrid en 1909, con ella en el papel de Melibea (Heras González 2009: 241-242).

10.- Fundada en 1973 por Carmen Zapata, Margarita Galbán y Estela Escarlata, se trata de una institución que todavía hoy trata de difundir el teatro en lengua española en Estados Unidos.

11.- Véase nota anónima en Celestinesca, 2, 2, Noviembre de 1978, página 34. 
en la inteligibilidad del texto que puede imaginarse. Las funciones fueron acompañadas de un simposio en la UCLA, donde Custodio pudo dialogar con los estudiantes.

Pese a lo atractivo del experimento, Custodio comprobó pronto que las condiciones de trabajo que le imponían desde la producción no le permitían trabajar con libertad, y que la dificultad de los esforzados actores bilingües por dominar el texto en ambas lenguas alejaba su montaje del perfil profesional que estaba habituado a ofrecer. La perspectiva del fracaso le abocó a una salida impensable para su concepción habitual de la escena:

Las dificultades que tuve que resolver para dar vida en un escenario inadecuado, con elementos técnicos de pobre calidad a mi nueva adaptación — dos horas y mediade La Celestina, me estimularon a redondear el espectáculo del que me sentí satisfecho como resultado artístico. No conté con más colaboración positiva que la de los actores, algunos de ellos admirables en sus papeles. La inexperiencia de críticos, espectadores y técnicos ante una obra maestra de la literatura clásica se hizo también manifiesta en los productores del espectáculo, a quienes llegué a proponer que presentáramos la Tragicomedia con trajes modernos de ensayo y sin escenografía como aquella inolvidable versión de Hamlet que yo presenciara en Broadway con Richard Burton bajo la dirección de John Gielgud. El sistema bilingüe — siete de los diez intérpretes participaron en las dos versiones- propio de las representaciones de la BFA no dio, en mi concepto, el resultado apetecido. La versión inglesa tenía fuertes contrastes de acentos en perjuicio de la emisión dramática, aunque la actuación fuera buena. El esfuerzo de memorización de aquellos bravos actores me pareció realmente heroico, pero una obra clásica tiene que contar con una dicción perfecta (Custodio 1979: 35).

Parece ser que la censura volvió a hacer de las suyas: «ni en la escena de Areúsa con Celestina y Pármeno en su casa, ni en la del jardín cuando Calisto desflora a Melibea, me fue permitido por los productores de la obra exponer mi concepción plástica» (Custodio 1979: n. 18). Así lo cuenta Custodio, aunque la verdad pudo ser diferente, dado que la intérprete de Melibea que debía mostrarse casi desnuda ante el público era nada menos que su hija Victoria. Se trataría, según Kathleen V. Kish (2007: 384), de un caso de auto-censura.

Esta versión hizo volver a Custodio al espíritu de sus primeras experiencias escénicas con La Celestina. Si atendemos a los testimonios que conservamos acerca de aquella versión, incluido el suyo, observamos que 
se produce un regreso a las formas iniciales, a la pobreza de medios y al «escenario de decoraciones simultáneas». Aunque las decisiones sobre la escenografía escaparon al dominio de Custodio y quedaron a cargo de Frances Acosta, de la "Bilingual Foundation", la disposición básica del escenario recuerda mucho al de La Celestina de 1953, aunque se pierda fluidez en las mutaciones

The sober architectural set is designed to suggest separate entrances to Calisto's and Melibea's houses, while Celestina's is fittingly placed in-between. The transitions from one scene to another, however, often seem abrupt and confusing. The theatre's physical structure and stage dimension probably do not allow for a more imaginative staging and movement. All the action is, in fact, confined to one level. This becomes particularly damaging, I believe, when Calisto rushes from the scene of his love-making to come to the aid of his watchful servants and falls from the ladder to his death. Since the staging offers no suggestion of physical danger, Calisto merely runs offstage, with distant voices announcing his death. With ladder or wall missing, the viewer is left without a sense of dramatic immediacy, and therefore untouched by the tragedy. (Mandel 1978: 37).

Aunque Custodio recupere el recurso de situar la muerte de Calisto fuera de escena, como en los montajes anteriores a 1968, no renuncia a sus progresos escénicos y se las arregla para mantener a Melibea en lo alto:

Por último, el monólogo de Melibea desde la torre antes del suicidio, lo resolví haciendo subir a la actriz hasta un balcón muy hermoso con adornos de caoba - reminiscencia arquitectónica de la antigua logia - que obligaba al público a ver la escena de lado. (Custodio 1979: 36).

Acostumbrado a aguzar el ingenio ante la escasez, Custodio resuelve y mejora aspectos del montaje que nunca le habían dejado satisfecho:

La escena a través de las puertas creó siempre un problema de visualización porque significaba condenar a uno de los amantes a no ser visto o a introducir un elemento adicional al decorado en medio de la escena o a hacerlo a través de una cortina de gasa, ninguna de cuyas soluciones me pareció acertada. En obra esencialmente realista, todo lo que sea recurrir a factores simbólicos parece descartado, pero el teatro tiene ya por naturaleza un muro ficticio que separa al público del actor. Las puertas que 
Calixto quiere romper para poder ver a Melibea fueron establecidas por la acción, con las manos en gesto mímico, acariciadas por los amantes como si fueran ellos mismos; el texto complementaba el suceso eficazmente, haciéndolo perfectamente claro (Custodio 1979: 35).

No sabemos si fue por los desvelos que le causó esta experiencia, pero Custodio no volvió a montar La Celestina, ni siquiera con la compañía vocacional que dirigió en El Escorial entre 1979 y 1986. Las tres versiones, correspondientes con tres concepciones escénicas que no son sino variantes de una sola, dan fe de la confianza de Custodio en la potencia escénica de La Celestina, y de lo mucho que había asumido como propia la «misión pedagógica» de divulgar la Tragicomedia, que, en sus propias palabras, "sólo podrá popularizarse a través del teatro» (Custodio 1979: 36).

\section{El orden}

En todas sus versiones, y la que publicó en 1966 es suficiente prueba de ello, Custodio trata de apegarse en gran medida a la disposición de la trama que propone el original. La invención de situaciones nuevas es escasísima, si la comparamos con la de otros adaptadores. En gran medida, su trabajo se limitaba a volcar los 21 autos de la Tragicomedia en un molde teatral, filtrando todo aquello que pudiera resultar prolijo o atentar contra el ritmo vivo que exige un espectáculo de duración convencional. Sin embargo, la intervención de Custodio va más allá de «un arreglo para llevar [La Celestina] a escena con una duración no mayor de tres horas» (Custodio 1966: 15), porque, por medio de estos cambios excusados por la reducción temporal, introduce su visión particular del clásico.

Custodio distribuye el drama en tres actos de desigual duración, que podemos subdividir en una sucesión de cuadros ${ }^{12}$ introducidos por indicaciones del lugar en el que sucede la acción, las mismas que se hicieron visibles mediante carteles en las primeras puestas en escena. En la siguiente tabla, podemos ver en la columna de la izquierda la estructura propuesta por Custodio en su versión de 1966, y en la derecha el «auto» o «autos» de La Celestina de los que, con más o menos variaciones, ha obtenido el material. Quedan indicados, además, los casos en los que encontramos textos de cosecha propia, verdaderamente escasos. El paréntesis

12.- Partimos del concepto de «cuadro» que define José Luis García Barrientos (2001: 76), es decir, "cada unidad espacio-temporal en el desarrollo del dama, cada secuencia, pues, delimitada por un cambio de lugar o por una ruptura de la continuidad temporal». Aunque Custodio no proponga explícitamente esa división de la acción, la importancia que para la puesta en escena de esta obra tienen los espacios nos permite privilegiarlos como elemento ordenador frente a otros factores, como la entrada y salida de personajes. 
con la indicación de lugar de la columna izquierda se cierra con el número de página en el que comienza cada cuadro en la edición de 1966:

\begin{tabular}{|c|c|}
\hline Actos y cuadros (Custodio) & Autos (Rojas) \\
\hline \multicolumn{2}{|l|}{ 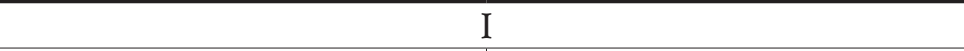 } \\
\hline 1 (Jardín de Melibea, 43) & 1 \\
\hline 2 (Casa de Calixto, 44) & 1 \\
\hline 3 (Casa de Celestina, 50 ) & $1+$ una página nueva \\
\hline 4 (Casa de Calixto, 55) & $\begin{array}{c}1+\text { dos páginas nuevas con } \\
\text { fragmentos de } 3\end{array}$ \\
\hline $5($ Calle, 59$)$ & 1 \\
\hline 6 (Cámara de Celestina, 62) & 3 \\
\hline 7 (Casa de Melibea, 63) & 4 \\
\hline 8 (Calle, 71) & 5 \\
\hline 9 (Casa de Calixto, 72) & $5-6$ \\
\hline 10 (Calle, 76) & 7 \\
\hline 11 (Casa de Areúsa, 77) & 7 \\
\hline \multicolumn{2}{|c|}{ II } \\
\hline 1 (Casa de Calixto, 84) & 8 \\
\hline 2 (Casa de Celestina, 88 ) & 9 \\
\hline 3 (Casa de Melibea, 97) & 10 \\
\hline 4 (Calle, 102) & 11 \\
\hline 5 (Casa de Celestina, 106) & $11+7+$ dos páginas nuevas \\
\hline $6($ Calle, 110) & 12 \\
\hline 7 (Casa de Celestina, 114) & 12 \\
\hline \multicolumn{2}{|l|}{ 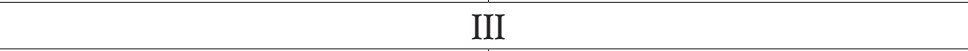 } \\
\hline 1 (Casa de Areúsa, 119) & $15+18$ \\
\hline 2 (Jardín de Melibea, 124) & $14+19+20+21$ \\
\hline
\end{tabular}

Como se puede comprobar con un rápido vistazo a la tabla, Custodio sigue con bastante fidelidad el orden de las escenas del original, salvo en el tercer acto, que sintetiza en sólo dos cuadros que ordenan los sucesos de un modo bien distinto. Hay amplios fragmentos cortados de todos los autos, en especial en el Acto I, donde perdemos el auto 2 completo y buena parte del 3; y en el Acto III, para el que desaparecen los autos 13, 16 y 17, en parte coincidentes con las interpolaciones de la Tragicomedia de 21 actos.

Tanto Peter G. Earle (1955) como María Rosa Lida de Malkiel $\left(1970^{13}\right)$, los principales comentadores de la versión de Custodio, trabajaron con 
un mecanoscrito que, creemos, se corresponde con la primera versión, la del estreno de 1953. Concretamente, Earle llegó a verla representada en México y tuvo acceso a una copia de 46 páginas que hoy se ha perdido. Él habla de un primer acto de nueve escenas y le calcula una duración de 45 minutos. La diferencia se explica si tenemos en cuenta que Custodio no incluyó el conjuro de Celestina a Plutón hasta la segunda versión, la de 1957 (Boletín de Teatro Español de México, septiembre y octubre de 1959). Esta omisión es la que nos hace deducir que Lida trabajaba también con la versión de 1953, ya que ella afirma que Custodio "ha suprimido el aparato mágico» (Lida 1970: 469).

\section{Análisis e interpretación}

A continuación, recorreremos el texto de La Celestina y nos transportaremos al momento en el que Custodio tomó el haz de decisiones en el que se resume el proceso de adaptación de una obra literaria al teatro. Además de aplicar nuestro propio bisturí, recuperaremos para la ocasión muchos de los minuciosos comentarios de María Rosa Lida de Malkiel, que en su libro La originalidad artística de La Celestina estudió la versión de Custodio entre las muchas otras obras surgidas de la imitación, refundición o adaptación de La Celestina durante estos últimos quinientos años. Conviene advertir que la finalidad del libro de Lida era demostrar esa "originalidad artística» que hace a la Tragicomedia insuperable no sólo frente a sus precedentes, sino ante todas sus herederas, reflejos pálidos e inevitablemente imperfectos. Aunque sus comentarios son agudos, sabios y certeros, Lida no reserva indulgencia para las necesidades de la reducción textual ni acepta de buen grado que el público de nuestro tiempo repudie buena parte de la alambicada retórica con la que se expresan los personajes de La Celestina. Vaya por delante que si bien estos presupuestos condicionan el criterio de la profesora y explican buena parte de su hipercriticismo, no llegan nunca a oscurecer la potencia iluminadora de sus comentarios ${ }^{14}$.

\section{Acto I}

Es en el primer acto en el que se muestra más conservador, donde respeta con más fidelidad el orden de su modelo y más rehúye las innovaciones. Su procedimiento consistirá en borrar o adaptar fragmen-

publicó en realidad en 1962, el mismo año del fallecimiento de la profesora.

14.- Tomaremos las citas de La Celestina de la edición de Julio Cejador y Frauca (1999, edición virtual, sobre la publicada en 1913), una de las que probablemente manejó Custodio. 
tos del original, sin modificar apenas acciones, personajes y espacios, y procurando conservar todo aquello que permita volcar a los personajes en escena de la manera más genuina, entendida ésta siempre desde su lectura particular.

Durante los dos primeros cuadros, es decir, hasta la aparición de Celestina, las modificaciones en el texto son mínimas, pero en cambio son muchos los borrados, asemejándose el trabajo de Custodio por un momento al de un censor que tachara líneas transgresoras de alguna ley teatral. Las escasas modificaciones obedecen al intento de representar gráficamente aspectos de la dicción escénica, como la transformación de la monótona -y misógina - retahíla de defectos de la mujer que lanza Sempronio en una serie, más expresiva, de preguntas retóricas (47), que es contundentemente contestada por Calisto con una frase añadida por Custodio: "Nada de eso reza con Melibea» (47). De este modo, el prolijo y laberíntico diálogo se hace sintético y directo.

Antes, Custodio ha simplificado el encuentro entre Calisto y Melibea mediante la eliminación de todos aquellos razonamientos que pudieran resultar redundantes, y cuyo sentido es mantenido en el texto salvado. La puesta en escena compensará con creces el texto perdido:

Creo que en esa primera escena de la obra sucede algo que escapa a la moral convencional pero que no inquieta a nuestra época: el ataque amoroso de Calisto a Melibea cuando la ve por primera vez en el huerto. De ahí parte del error primario de la crítica por atenerse de modo estricto a la letra olvidando que como obra dramática la acotación — según señala en otros casos María Rosa Lida de Malkiel - va implícita en el diálogo. Sobre la escena se puede mostrar claramente, y así lo he hecho yo cuando he dirigido la obra en distintas ocasiones desde 1953 a 1968. (...) Para Calisto ese galardón que él juzga superior a la silla sobre los santos en el cielo es el cuerpo de Melibea, en ese mismo instante, sin más dilación. Y así se produce lo que Melibea llama loco atrevimiento: Calisto trata de abrazarla y ella lo rechaza con violencia ante el intento del joven de comunicar su deleite con ella en ilícito amor. (Custodio 1977: 479).

A continuación, Custodio borra la primera discusión de Sempronio con Calisto, que, en cambio, solicita directamente a su criado el laúd y empieza a cantar sus penas. La acción del laúd, que expresa a la vez la situación lastimosa de Calisto y la actitud burlona de Sempronio (reducida al elocuente comentario "destemplado está el laúd»), queda así privilegiada frente a la más elaborada y verbal querella del original. Para nosotros, 
síntesis y búsqueda de lo concreto para su traducción a medios escénicos; para Lida, «antipatía a la lentitud oratoria» (1970: 640).

La mayor parte de los borrados que siguen cumplen esta función de resumen, a excepción de otros que resultan menos explicables por lo que sacrifican: los apartes maliciosos de Sempronio, fuente garantizada de comicidad para la escena. Sucede algo curioso con respecto a los apartes. Por un insospechado afán de verosimilitud, Fernando de Rojas hace que las intervenciones en aparte de los criados o de Celestina sean con frecuencia audibles, aun como murmullos, para los otros personajes. Custodio prefiere atenerse a la convención escénica más habitual, y, o bien los sacrifica, como sucede a menudo en este primer acto, o bien los transforma. Así interpreta Lida esta decisión: «Custodio ha tratado de reducir el número de apartes, ya por prestar menos atención a los personajes 'bajos', ya por sentir el recurso como una rutina artificiosa» (Lida 1970: 148). También puede entenderse como una manera de "teatralizar» $\mathrm{La}$ Celestina, acomodándola a las convenciones que ya le son familiares a un espectador de teatro clásico.

Pasamos a casa de Celestina en el cuadro 3. Tenemos ante nosotros un primer ejemplo de reconstrucción de una escena: Custodio elimina el diálogo inicial entre Celestina y Elicia, y la acción comienza directamente con la llegada de Sempronio a la casa. ¿Por qué? Quizá para facilitar la transición, o para no sacar innecesariamente a Sempronio de escena. También resulta más verosímil que Celestina sepa que Crito está en casa, de forma que se convierta en innecesaria - y por lo tanto, borrablela explicación de Elicia. El comentario de la muchacha, "Ay, triste!», es dicho ahora a Sempronio, y no a Celestina, lo que acentúa un tanto la astucia e hipocresía de la joven, cuyos sentimientos reales hacia Sempronio se muestran ahora más ambiguos. Para recomponer la escena en esa dirección, Custodio añade unas cuantas líneas, entreveradas con las del original, hasta sumar en conjunto casi una página nueva, bien conjugada en cuanto al estilo con el resto. Reescribe así la escena de modo que la astucia de Elicia y Celestina se hace más evidente, así como la ingenuidad de Sempronio. Por otro lado, ahora Elicia no se va de escena, sino que simplemente calla (53). La actitud que Celestina muestra aquí, «los arrumacos con que pondera a Sempronio el amor de la moza que le está engañando, el aparte agregado a las afectuosas palabras con que le recibe», es indicio para Lida de la construcción de una Celestina «más dura y cínica que la del original» (Lida 1970: 591).

Una vez tejida la telaraña de Celestina y Elicia sobre Sempronio, lo que interesa ahora es que Sempronio introduzca sin más dilación el encargo de Calisto: Custodio elimina todo circunloquio previo y reconstruye el texto con habilidad sintetizadora (54). La inclusión aquí de una referencia al tiempo que lleva padeciendo Calisto de amores («sin dormir pasa las noches»), es destacada por Lida como ejemplo de lo mucho que se espon- 
ja el tiempo en esta versión (Lida 1970: 197). Así mismo, con sus elecciones Custodio hace hincapié en la complicidad de Celestina y Sempronio, en el impreciso pacto que les llevará a la muerte.

Convenientemente aligerada de algunos circunloquios más o menos redundantes, Custodio mantiene la discusión de Pármeno con Calisto. Así sucede con la sarta de vilipendios que Pármeno deja caer sobre el nombre de Celestina. En cambio, elimina casi por completo la intervención de Sempronio en el diálogo entre Celestina y Calisto con el fin de reforzar un único vector dramático: la persuasión de Calisto por Celestina. Para ello, introduce aquí un importante añadido, que llega casi a las tres páginas (57-59) y que consiste en un diálogo entre Celestina y Calisto, para el que recupera buena parte de lo que se dicen Celestina y Sempronio en el auto 3 del original. Parece que Custodio juzgaba confuso que no se produjera o se elidiera la conversación en la que Calisto "contrata" los servicios de la alcahueta, o que se produjera de forma vicaria a través de Sempronio. A propósito, Custodio añade en su versión un cierto disimulo del que hace gala Celestina, recreado en paralelo al que utilizará con Melibea después. Lida confiesa su disgusto con esta decisión, que "aquilata la cuidada contextura del original»: el hecho de que Celestina informara de sus planes a Sempronio y no a Calisto subrayaba según ella "la incapacidad del soñador para la acción práctica» (Lida 1970: 405). El Calisto de Custodio, que tan sólo opone una tímida protesta a las maledicencias de la alcahueta («nada de eso reza con Melibea»), resulta así un poco más mezquino y materialista, y enseguida se deja llevar por las facilidades y garantías que le ofrece Celestina.

En estas nuevas páginas, Custodio hace uso de toda la imaginería de la lírica amorosa medieval de raigambre petrarquista, especialmente para la descripción de Calisto de sus propios sentimientos (lucha de opuestos, fuego que consume, etc., 58) e incluso de tópicos sobre la naturaleza ambigua del desdén femenino, algunos de su propia cosecha (59). Por otro lado, parece que también quiere Custodio que el diálogo siguiente entre Pármeno y Celestina forme parte de un mismo plan de batalla: tras ganarse al amo, corresponde conquistar al criado. Poco a poco vamos comprobando que la constante simplificación de la acción refuerza las líneas de causalidad del texto dramático, especialmente las que se vinculan a Celestina, pero reduce la sutileza psicológica con la que los personajes estaban trazados en el original.

A continuación, sitúa el diálogo entre Pármeno y Celestina en la calle, fuera del alcance de los oídos de Calisto (59). En una nueva estrategia de concentración dramática, elimina a Sempronio de esta conversación, dejando aislados a los dos personajes. También omite las consideraciones generales sobre lo poco fiables que son los señores, y pasa directamente a aquello que tiene implicaciones en la acción dramática: la exhortación de Celestina a que se ponga de su lado y que deje de aconsejar a su amo. 
De este modo, y con sus artes habituales, quiere Celestina quitarse de en medio un enemigo (61).

Hasta tal punto ha concentrado Custodio la acción que consideraba de valor dramático, que decide que ha llegado el momento de dar un gran salto. El elemento desencadenante de la acción, sus prolegómenos, han sido ya claramente expuestos: podemos pasar directamente a la acción protagonizada por Celestina. Esta hipótesis explica el borrado más importante hasta el momento, que abarca casi dos autos completos del original: el segundo auto y la mayor parte del tercero. Como consecuencia, se privilegia el recorrido y el protagonismo de Celestina pero se simplifica considerablemente la trama de los criados y su propia caracterización. La pérdida más grave radica en la minimización de la vida interior de Pármeno. En el desaparecido auto 2, era el desdén desagradecido de Calisto ante sus sinceros consejos lo que provocaba la desafección de Pármeno. Este primer desengaño le hacía, a su vez, más sensible a las tentaciones corruptoras de Celestina y Sempronio. Ahora, una vez desaparecida cualquier motivación interna, Pármeno queda como un muñeco de trapo con el que Celestina puede jugar a su antojo. Perdida su evolución emocional, se convierte en un personaje contradictorio que pasa inexplicablemente de la tozuda resistencia que muestra en el cuadro 5 a una rápida claudicación en el 10. No se equivoca Lida cuando afirma, respecto a los criados, que «la atenuación de sus rasgos emana de las directivas generales del adaptador más que de la reconsideración deliberada de cada sirviente» (Lida 1970: 640).

Para Custodio todo lo que separa el pacto de Calisto con Celestina y el comienzo de su abordaje a Melibea son distracciones de la acción principal. Por eso pasamos directamente a la escena del conjuro. El salto parece grande, pero, por lo visto, lo era aún más en la versión inicial, la de 1953, y lo fue de nuevo en 1978, ya que en ninguna de las dos aparecía. La decisión inicial de prescindir de esta escena podría estar ligada a la perspectiva con la que Custodio encara su versión. Si para él Melibea no era víctima de un hechizo, sino de la represión y el sistema moral de una sociedad que le impedía expresar libremente su atracción hacia Calisto, esta escena estaría de más. La decisión de incluirla en la versión que publicó en 1966 no obedecería a un cambio de actitud, sino a la indudable espectacularidad de la que esta escena está dotada y a la certeza de que no es incompatible, en rigor, con la lectura de una Melibea enamorada desde el inicio.

Precisamente para evitar la acumulación de monólogos, Custodio elimina el que mantiene Celestina consigo misma ${ }^{15}$ al comienzo del auto 4 , y nos sitúa directamente en el interior de la casa de Melibea. Perdemos numerosos matices de la intrincada psicología de Celestina, pero ganamos, 
de nuevo, agilidad dramática. La razón principal para el borrado de líneas del auto cuarto es la eliminación del personaje de Alisa, madre de Melibea. Consideraba Custodio que la participación de este personaje en el drama era tan limitada, que no tenía sentido económico mantenerlo en su versión. Además, la progresiva y sutil conversión de Pleberio en un padre celoso al uso del teatro del siglo de oro queda reforzada si se le deja solo.

En cuanto al diálogo entre Celestina y Melibea, Custodio se limita a borrar todo aquello que ya está expresado de manera sintética en las palabras que quedan en su versión (64-65). Las apostillas de Lucrecia, a diferencia de las de los criados de Calisto en su respectivo encuentro con Celestina, son mantenidas en su mayor parte, pero Custodio procura que sea Celestina, y no Melibea, quien se encargue de replicarlas, quizá para marcar escénicamente la distancia social que separa al ama de su criada. El riguroso adelgazamiento del diálogo entre Celestina y Melibea tiene consecuencias negativas inversamente proporcionales a la agilización de la acción. Por ejemplo, Custodio prescinde del discurso con el que Celestina pretende embelesar a Melibea, en el que dilataba la resolución de tal modo que le generaba a ésta un ansia incontrolable de conocer a quién se refería. Perdemos así parte del ingenio de Celestina, al optar Custodio por adelantar en lo posible el nombre de Calisto (66-67), probablemente con la intención de que la reacción airada de Melibea, y con ella la escalada agónica del conflicto, llegue lo antes posible

Justo al inicio de esta respuesta de Melibea, de esta furibunda reacción contra el nombre de Calisto, Custodio añade en cambio un comentario muy llamativo: "Ganas me dan de llamar a mi padre para que te dé tu merecido» (67). Esta adición es comentada por Lida como prueba de la transformación del personaje de Pleberio en un "defensor de la honra» cercano a la tipología del Teatro del Siglo de Oro, la que ha dado lugar a la «actitud hispánica tradicional» (Lida 1970: 487) que Custodio parece tener en mente en su visión particular del drama.

En cuanto al pretexto de Celestina, la petición del cordón y de la oración de Santa Apolonia para el mal de muelas de Calisto, el texto se mantiene en su mayor parte, con las correspondientes actualizaciones, aunque hay alguna variación de interés: tras mencionar brevemente el desenlace fatal que le corresponderá a Calisto si nadie intercede por él, Celestina calla. Custodio elimina así la acusación de falta de misericordia del original. La astuta estrategia de la Celestina custodiana alude a la compasión de Melibea, y no a su vergüenza: eludiendo el riesgo de encorajinar de nuevo a Melibea con acusaciones agresivas, se limita a pintar un cuadro lastimoso sobre la muerte de Calisto. El cambio encaja perfectamente con la Celestina callada y sigilosa que se va configurando, a fuerza de cortes, en la versión. Así mismo, Custodio añade unos significativos puntos suspensivos que, suponemos, se corresponderían con unas marcas de dirección que subrayarían el cambio de actitud de Melibea: 
Melibea: Espera... si eso querías, ¿por qué no me lo dijiste sin rodeos?... ¿Y qué tiempo ha...? (68).

De nuevo para reforzar el personaje del padre, Custodio introduce un par de intervenciones en las que queda manifiesta su autoridad en la casa, ante la que deben tener cuidado tanto Celestina como la propia Melibea. Así dice el original:

MelibeA.- ¡O quanto me pesa con la falta de mi paciencia! Porque siendo él ignorante e tu ynocente, haués padescido las alteraciones de mi ayrada lengua. Pero la mucha razón me relieua de culpa, la qual tu habla sospechosa causó. En pago de tu buen sofrimiento, quiero complir tu demanda e darte luego mi cordón. E porque para escriuir la oración no haurá tiempo sin que venga mi madre, si esto no bastare, ven mañana por ella muy secretamente.

LuCRECIA (Aparte).- ¡Ya, ya, perdida es mí ama! ¿Secretamente quiere que venga Celestina? ¡Fraude ay! ¡Más le querrá dar, que lo dicho!

Y así queda en la versión de Custodio:

Melibea: Casi me arrepiento ya de la falta de mi paciencia. Harto me dejé llevar de mi cólera, pero no quiero que me juzgues cruel y sin entrañas. Te daré de buen grado el cordón, que no quiero tener sobre mi alma la pena de haber dejado padecer a un triste, estando en mi mano el remedio. Y si el cordón no basta, ven por la oración.

Celestina: Sí vendré, pero enojarase tu padre si acaso me viese.

MeLibeA: Ven recatada y yo haré que secretamente nos veamos.

LUCRECIA: (Ya, ya... pobre de mi ama. En secreto quiere hablar con Celestina. Algo más le dará que la oración) (69).

Se sustituye así la referencia de la madre por la del padre y, además, es ahora Celestina, gracias a su propia astucia, quien consigue una cita secreta, que en el original era sugerida directamente por Melibea. De este modo se justifica mejor todavía la suspicacia de Lucrecia.

A continuación, Custodio suprime la prolija discusión que mantienen Celestina y Sempronio y la obstinación de este último en saber cómo fueron los negocios con Melibea. Sempronio ya no insiste más, como en el original, sino que se limita a acceder a la petición de Celestina de apremiar el paso hacia la casa de Calisto y a injuriarla por lo bajo. Esta simplificación es condenada por Lida: «donde Rojas subraya la inferio- 
ridad intelectual del criado, Custodio le asigna, en cambio, una castiza maldición, es decir, destaca exclusivamente la faz emotiva del personaje» (Lida 1970: 641).

Dado que el contenido del auto sexto es en gran medida informativo, Custodio corta sin piedad la mayor parte de los diálogos y conduce la acción hacia aquello que puede hacer de este cuadro un eslabón efectivo en la cadena de peripecias del drama celestinesco: la entrega del cordón, a través del cual Celestina sigue ganándose a Calisto. La acción se agiliza de nuevo, aunque se pierden pormenores y el juego de la negociación, así como las hiperbólicas exclamaciones de Calisto, contrapunteadas por la ironía de Pármeno (74). Lida considera esta omisión como un atentado a la causalidad del relato, porque, en su opinión, vacía de sentido la entrega posterior de la cadenilla por Calisto, en el auto 11 (Acto II, cuadro 4, en Custodio): "dicha supresión convierte la dádiva de la cadenilla, que provoca la codicia y la muerte de los tres cómplices, en un azar externo, no en la consecuencia trágicamente irónica del juego de ansias y odios de los personajes mismos» (Lida, 1970: 248). Lo cierto, como veremos en su momento, es que Custodio tendrá especial cuidado en darle el suficiente relieve a la entrega de la "cadenilla» y al círculo de codicia y sangre que se cernirá en torno a ella.

Ya ganado definitivamente Calisto, a continuación Celestina reemprende la conquista interrumpida de Pármeno. Custodio elimina la larga digresión de Celestina en la que evoca su relación con su madre, Claudina. Lida critica esta omisión, porque hace menos comprensible la reacción airada de Pármeno en el momento del asesinato, es decir, el acto II, cuadro 7 (116-117; Lida 1970: 248). Más que despreciar la información, parece que Custodio pretendiera volcar en la puesta en escena lo que en el original es puramente verbal. Sólo así se explica la radical simplificación que hace Custodio de la escena en la que Celestina blande el nombre de Areúsa para seducir a Pármeno. El extenso corte deja perder muchos matices de la pasión de Pármeno, y el trato con Celestina tiene así un aire casi comercial. También introduce Custodio unos puntos suspensivos entre «Mu...»y "...chachas» (77) que parecen recoger una actitud interpretativa que dejaría ver la sorpresa y el interés del infantilizado Pármeno, y a la vez el poder que Celestina ejerce sobre él. Lida lo reprocha: «Custodio suprime, en suma, la evolución de Pármeno, ya que le muestra inflexible hasta que Celestina le ofrece su tentadora mercancía, e inmediatamente vencido así que se la ofrece» (Lida 1970: 641). El siguiente paso es ya el encuentro sexual. Para ello, Custodio introduce un cambio de espacio: de la "calle» a "Casa de Areúsa», donde se desarrolla lo que llamamos cuadro 11 del acto I. En esa mutación, sin mencionarlo, ha desaparecido Pármeno, quedando a solas Celestina y Areúsa (77). Es a la muchacha a quien Celestina debe seducir ahora, para que acceda a tener relaciones con Pármeno. Custodio borra muchos de los argumentos de la alcahueta, 
confiando en que la interpretación, las miradas y los silencios sean suficientes para dejar claro el sentido de la acción (78). Sólo así tiene sentido pleno la escena resultante tras tantos cortes, porque de la mera lectura no se entiende cabalmente por qué se vencen tan fácilmente las resistencias de Areúsa. Aspectos de suma importancia, como el momento en el que Celestina arranca a un Pármeno hechizado por la belleza de Areúsa la promesa de que le servirá junto a Sempronio, mantienen intacto el texto del original. Si descontamos el componente escénico, comprendemos que Lida criticara severamente estas omisiones, sumadas a las que se refieren al diálogo con Pármeno: «empequeñecen el papel de la tercera, que ni agota las objeciones del mozo, ni le somete enrostrándole la infamia de su madre y atizando su sensualidad, ni predica a la muchacha su lasciva filosofía y sus interesadas lecciones.» (Lida 1970: 592)

En cuanto al encuentro entre Celestina y Elicia, Custodio prefiere situarlo en el cuadro 5 del acto II (107-108) con el fin de alargarlo. Es en esta escena, a la mitad del auto séptimo, cuando Custodio pone fin a su Acto I. No es casualidad: Celestina termina este acto de presentación en lo más alto de su ascenso: ha convencido a Melibea de que le preste su cordón, ha encandilado a Calisto y ha conseguido vencer las dudas de Pármeno, que se ofrece finalmente a estar a su servicio. Ese final climático es ideal para bajar por primera vez el telón (83).

\section{Acto II}

El segundo acto de la versión de Custodio reconstruye básicamente los autos que van del 8 al 12 en el original. La técnica y los recursos de Custodio como adaptador vienen a ser los mismos del acto I, si bien da un paso adelante en la recreación libre del drama en el muy reconstruido cuadro 5 , que, partiendo del auto 11, es transformado mediante páginas nuevas e injertos del auto 7 del original. Lo veremos detenidamente.

Para comenzar el acto segundo, Custodio nos lleva directamente a casa de Calisto, donde hablan Pármeno y Sempronio, y elimina la breve introducción con la que comienza el auto octavo del original, aquella en la que aparecen Pármeno y Areúsa en el amanecer de su noche de amores. Se trata, según Lida, de una elipsis frecuente entre los adaptadores del siglo xx, en la que coincide Custodio con José Ricardo Morales y el dúo Escobar-Pérez de la Ossa (Lida 1970: 162). El diálogo entre ambos se simplifica considerablemente. Su alianza se lleva a cabo, aunque Custodio prefiere expresarla con pocas palabras. La expresión no verbal, suponemos, haría el resto. Lo mismo sucede con la descripción borrada del estado de Calisto, ya que su aparición en escena habla por sí misma: en cuanto Pármeno pregunta "¿y qué hace el desesperado?», entra Calisto desafinando una cuarteta. Los jocosos comentarios que hacen a propósito los criados son 
a veces mantenidos («SEMPRONIO: ¡Hideputa el trovador!», 86) y otras sustituidos por acotaciones ("(Ríen los criados)», 86).

El cambio de auto en el original se traduce en la versión con un cambio de espacio: de la casa de Calisto a la de Celestina, para recrear el célebre auto 9, el de la comida en casa de Celestina, en el cuadro 2 del Acto II. Aunque no deja de limpiar la escena de sentencias y expresiones redundantes, Custodio es aquí más indulgente que en otras ocasiones con todos aquellos diálogos que no tienen un valor dramático evidente. Eso se debe a la naturaleza misma de la escena, en la que efectivamente la acción apenas avanza, pero que resulta imprescindible por lo mucho que nos cuenta de los seis personajes y de su visión del mundo. Al final, añade una escena sin palabras para mostrar la borrachera de Sempronio y que se desarrollaba simultáneamente al diálogo de Celestina con Lucrecia: «When the dinner is finished and Celestina departs with Lucrecia, Sempronio passes out on the floo. Elicia wipes the grease from her hands with his hair as she tries to revive him» (Earle 1955: 50). Earle pone esta escena como ejemplo de que Custodio no ha tratado de modernizar el sentido del humor (a diferencia de Achard, que introdujo diálogos sutilmente irónicos), sino de hacer más evidente el humor que ya subyace al texto y que no suele percibirse en la lectura: «The dining scene, for example, is funny, yet what laughter it may inspire depends more on how things are said and done than on what is said» (Earle, 1955: 51). Lida, por su parte, comenta que el carácter de Elicia se mantiene y refuerza con este tipo de agregados (Lida 1970: 692).

Es en el cuadro siguiente, el tercero del segundo acto, donde Custodio realiza una de las transformaciones más importantes: la que afecta al monólogo inicial de Melibea (97-98), al que modifica considerablemente siguiendo las siguientes líneas:

- Introduce, justo al comienzo, una referencia al padre, al que Melibea teme aunque no sospeche nada, dentro de la «acentuación de la función del padre como defensor de la honra» de la que habla Lida (1970: 487).

- Cuando expresa su arrepentimiento por no haberse entregado antes, elimina la referencia concreta que situaba el encuentro con Celestina "ayer» por el más indefinido "en un principio», referido no a la mediación de la alcahueta sino al encuentro primero con Calisto.

- Custodio añade inflamadas loas a Calisto de parte de la enamorada Melibea, con imágenes más o menos propias de la época pero escritas absolutamente por él, incluido un desafortunado ripio ("sus miradas... flechas que aquí, para siempre, quedaron hincadas», 97). Custodio cierra el discurso con una sentencia fatalista ("...que sepa que Melibea es suya y muera luego", 98) que deviene en evidente 
profecía (recordemos que en México la palabra «luego» mantiene el sema de inmediatez que ha perdido en el castellano de España).

- Custodio reconstruye lo que sí está en el texto, es decir, el arrepentimiento de Melibea por no haberse entregado antes, el miedo de que Calisto, despechado, se vaya con otra, y su vergüenza ante Lucrecia.

- Custodio elimina las consideraciones ante Dios y sobre la condición femenina.

Lida juzga desfavorablemente esta transformación porque, en su opinión, «impone un sesgo romántico, ajeno al original» (1970: 135), que, sin embargo, encaja perfectamente con el personaje que Custodio dibuja en su artículo «Sobre el secreto de Melibea» (Custodio 1958).

A continuación, Custodio realiza importantes cortes en el diálogo entre Melibea y Celestina. Mediante el borrado, retarda la aparición del nombre de Calisto, de modo que el diálogo se asiente en la pura sugerencia: ambas saben de quién hablan, pero ninguna lo dice. Así es más efectivo cuando luego Celestina lo menciona como remedio para el mal de Melibea y justifica mejor la tremenda impresión que le causa, mantenida sin alteración por Custodio y reforzada escénicamente con el desmayo de la joven, como queda atestiguado por dos de las fotos que ilustran la edición de 1966. Lo cierto es que el carácter de Celestina ha cambiado como resultado de los cortes: es ahora más decidida, más taxativa, va directamente al imperativo sin pasar por el subjuntivo. La Celestina de Custodio no necesita justificarse: simplemente, actúa

Custodio prefiere que sea Sempronio y no Celestina quien inicie la acción del cuadro 4, basado en el auto 11. Facilita así el cambio y permite que ella pueda aparecer por sorpresa, interrumpiendo el diálogo entre Sempronio y Calisto. Evita además esos ingenuos y redundantes avisos, más propios del teatro leído que del representado, en los que los personajes anuncian con palabras lo que el espectador puede ver directamente con sus ojos ("Celestina: A Pármeno e a Sempronio veo yr a la Magdalena»). Hacia el final de la escena, Custodio realiza unos sutiles pero significativos cambios: con el fin de dejar solos a Sempronio y Pármeno, adelanta la salida del escenario de Calisto, que, en lugar de regresar a casa para descansar y preparar el tan ansiado encuentro, se lanza en persecución de Celestina, lo cual, por cierto, revela mejor todavía la eficacia de las artes de la hechicera.

Custodio transforma por completo el cuadro 5. Celestina ha logrado su victoria y ahora disfruta de su botín. Para mostrarlo, recupera un fragmento borrado que mostraba un anterior encuentro con Elicia y que se situaba al final del auto séptimo, y añade casi dos páginas de texto nuevo en el que Celestina muestra su fascinación por el dinero. Aunque, como señala Snow (1997: 2006), la mayoría de los adaptadores subrayan la 
codicia de Celestina, Custodio lo hace en tal grado que termina por empobrecer al personaje, al convertir este vicio en su casi única motivación. El agudo comentario de Lida nos ayuda a entender el procedimiento de Custodio:

La reelaboración de Celestina destaca sistemáticamente uno de sus rasgos de carácter, una de sus actividades profesionales, una de sus actuaciones, y le subordina las restantes. Y no por afán de concisión - ya que hay frases $y$ hasta escenas enteras agregadas-, sino para simplificar y concentrar la multiplicidad y amplitud del modelo. (...). El predominio de la codicia ha desalojado como motivación a la conciencia profesional que, emparentada con el sentido de la honra, daba hondura humana a la alcahueta. (Lida 1970: 592).

Es probable que Custodio hubiera querido añadir una nueva línea de ironía trágica: el dinero no sólo no alargará la vida de Celestina, sino que será la causa directa de su muerte. Sin embargo, la reducción a la que Custodio ha sometido el personaje de Celestina no puede justificarse suficientemente por exigencias dramáticas. Una Celestina cuya motivación fuera la supervivencia, o al menos mantener cierto estatus de dominio sobre su pequeña corte de miserables, sería un personaje tan dramáticamente eficaz como el avaro en el que la ha convertido Custodio, y en cambio mucho más vivo y humano ${ }^{16}$.

El auto 12, que incluye la visita de Calisto a Melibea a través de las rejas y la escena del asesinato de Celestina, es dividido por Custodio en dos cuadros, el sexto y séptimo de este Acto II. Es al diálogo entre Melibea y Calisto a lo que Custodio presta más atención. Custodio omite cualquier interrupción, ni siquiera como alivio cómico, en la inflamada escena de los amantes (112). Una vez que Calisto ha conseguido la cita, su discusión con los siervos se reduce a una mera despedida. Lida considera que estos cortes impiden que "pueda percibirse el efecto corruptor del cambio» en los criados (Lida 1970: 641). En efecto, el apresuramiento con el que Custodio resuelve esta escena parece precursor del que caracterizará al Acto III. No cabe duda de que la acción avanza rauda, y que Custodio deja en pie aquello que afecta a la acción principal y mantiene recta la línea de causalidad de la obra.

Nos encontramos ya en un momento decisivo en el drama: el cuadro 7, aquel en el que Pármeno y Sempronio cometen su asesinato y se inicia la espiral de sangre por la que se derramará la Tragicomedia. En un primer momento, Custodio mantiene la mayor parte del texto, borrando sólo

16.- No por casualidad compara Mandel a esta Celestina con el célebre personaje de Molière: "The chest and the money it contains are an extension of her person, not unlike the similar situation in Moliere's The Miser», Mandel 1978: 38. 
expresiones un tanto redundantes o aquellas que no tienen consecuencia, como la petición de comida de Pármeno. Pero a continuación hace un borrado importante con el fin de acelerar la violencia de la acción. Las moderadas consideraciones iniciales, la suave transición que va de considerar lo que les debe Calisto a solicitar lo que les debe a Celestina, que entiende rápidamente las insinuaciones, son sustituidas por una rápida y brusca petición del dinero. Las razones de Celestina no serán rebatidas más que con amenazas (116-117). La escena ha ganado sin duda en violencia y brutalidad, y aunque muy reducidas, las réplicas que tratan de dilatar la acción consiguen mantenerla lo suficientemente tensa.

En el momento en el que los criados se deciden a matar a la alcahueta, los rápidos diálogos situados alrededor del asesinato se mantienen intactos, aunque Custodio añade una coda final: un breve lamento de Elicia por la muerte de Celestina, para colmar la tragedia de su muerte y cerrar en alto el acto segundo. No es casual que Custodio haya situado esta escena al final del Acto II. Si el primer acto había terminado con una muestra del dominio de Celestina sobre los demás, ahora las tornas han girado 180 grados. La frágil armonía con la que habían funcionado todos los engranajes de la máquina celestinesca se han roto. Lo que queda es tragedia. En nuestra opinión, dar por terminado aquí el segundo acto impone una pausa tensa que agiganta la tormenta que se avecina.

\section{Acto III}

El tercer acto supondrá el desenlace definitivo de la acción. Es, con diferencia, el más corto en número de páginas (I, 40 pp.; II, 34 pp.; III, 14 pp.). Es aquí donde Custodio introduce más modificaciones, creando cuadros que combinan escenas que en el original tenían otro orden, y también donde borra más cantidad de texto, eliminando autos completos.

Quizá por continuidad con el final del Acto II, nos vamos directamente a casa de Areúsa, donde ella se encuentra con Elicia. Por las dos muchachas conoce el público, enseguida, la muerte de Sempronio y Pármeno, cosa lógica una vez eliminados los personajes de Tristán y Sosia, que son los que dan la información por primera vez en el original. Mientras Elicia y Areúsa hablan, Centurio permanece escondido y desconocido todavía para el público, como esperando a recibir un encargo de parte de las muchachas: la de vengador de las muertes de los criados (119-121). Centurio no aparecía en la primera versión (Custodio 1960), pero lo introdujo en la versión publicada, todavía en los tiempos de la prohibición, y apareció en escena sólo en la renovada versión de 1968 para el Teatro Reforma. Según Custodio, fue la primera vez "en México y en España» en la que se representó "la escena entre Centurio, el rufián cobarde, con Elicia y Areúsa» (Boletín de Teatro Español de México, enero-febrero de 1968). En 
1978 este cuadro tuvo al parecer bastante éxito, quizá porque, como él mismo dice, dio «un salto hacia lo irreal» y convirtió la escena en "farsa» (Custodio 1979: 35).

En un detalle de habilidad dramatúrgica, Custodio acierta a conservar un fragmento que en cualquier otro momento habría borrado: el relato (aun así, resumido) del asesinato de Celestina, en boca de Elicia. ¿Por qué no borrar un discurso que repite lo ya mostrado en escena? Porque nos informa de la posición de Elicia respecto al conflicto, no tan favorable a Celestina como se podría pensar. En todo caso, Custodio reduce y resume los lamentos de las muchachas y pasa directamente a las palabras que generan acción: los planes de venganza de Areúsa (121). La urgencia es tal que no hay lugar para explicaciones ni aclaraciones sobre cómo sobrevivirán Elicia y Areúsa sin la ayuda de Celestina. La propuesta de Custodio, una variante fundamental, es situar aquí el diálogo de Areúsa y Centurio que en el original está en el auto 18, de modo que la sombra y amenaza del asesinato pese ya sobre Calisto y Melibea en su inmediato encuentro en el jardín de la dama, que Custodio ha preferido poner a continuación.

Aunque ya hemos visto que cambió de opinión en la última de sus Celestinas, la de 1978, tanto en la versión publicada en 1966 como en las anteriores Custodio decidió reunir en uno solo los dos encuentros de Calisto y Melibea que en el original se desarrollaban en los autos 14 y 19. Lida (1970: 469) señala la coincidencia de Custodio con la versión inglesa de 1707 al tomar esta decisión de unificar los encuentros.

Dado que Custodio sitúa en el mismo espacio ("Jardín de Melibea») la muerte de Calisto, el suicidio de Melibea y el monólogo final de Pleberio, consideramos que los autos 14, 19, 20 y 21 se reúnen en un único cuadro final, el segundo del Acto III. El trabajo de síntesis es enorme, si tenemos en cuenta que este cuadro no resulta mucho más extenso, en número de páginas, que los anteriores.

Del auto 14 sólo conserva unas pocas líneas, las que nos presentan al inicio a Melibea y Lucrecia esperando la llegada de Calisto. A Custodio no le interesa este encuentro, sino aquel que desembocará en la muerte de Calisto, y mucho menos las prolijas consideraciones del galán con ejemplos de la antigüedad clásica incluidos. De todos modos, el omitido atrevimiento de Calisto en esta escena, esta vez sí consentido por Melibea, le sirve a Custodio para justificar una decisión de puesta en escena: que Calisto se propase en el encuentro con el que se inicia la obra:

El complemento de esta situación [la de la escena inicial] se halla en el Aucto XIv: Calisto no deja pasar un instante tras la turbación que le produce el primer abrazo que puede dar a la doncella ya sin resistencia para llevarla al acto carnal. Cuando ella se cree obligada a llamarle al orden sin mucha convicción le replica el fo- 
goso galán: «Nadando por este fuego de tu deseo toda mi vida, ¿no quieres que me arrime al dulce puerto a descansar de mis pesados trabajos?» Imagen de dudoso vuelo poético pero de innegable clarividencia al resumir el acto frustrado de la primera escena y la espera en la media penumbra de su alcoba a que la alcahueta hiciera su trabajo: provocar a lujuria a la supuesta peña que era Melibea (Custodio 1977: 480).

En cuanto a las razones del borrado completo del auto 16, podemos suponer que Custodio quería ser coherente con la eliminación de Alisa y no dilatar el desenlace de la acción. ¿Qué perdemos? La trágica ignorancia de los padres, que al menos por lo que afecta a Pleberio, tiene valor dramático, y las sutiles justificaciones y decisiones personales de la valiente Melibea. Según Lida, perdemos un "delicado» ejemplo de alternancia de diálogos simultáneos (Lida 1970: 162), aunque la omisión encaja con la configuración del personaje de Pleberio como amenaza latente y celosa de la honra de su hija, incompatible con las «muestras de ternura e intimidad» (Lida 1970: 487) que aparecen en esta escena. ¿Qué ganamos? Una acción trepidante y un incremento en el patetismo trágico del encuentro en el huerto.

El auto 17, en el que Elicia y Areúsa hablan con Sosia, es también eliminado por Custodio, dado que no tiene ninguna consecuencia con respecto a la acción principal, esto es, la que llevará a las muertes de Calisto y Melibea.

Volvamos pues al segundo y último cuadro del acto III. Del auto 19 Custodio sólo salva parte de las canciones que Lucrecia y Melibea entonan para aliviar la espera, así como los diálogos de Melibea con Calisto que terminan con la muerte de éste. La espera de las dos mujeres conecta con los fragmentos del auto 14 en los que sucedía lo mismo. No sólo Tristán y Sosia son reducidos a unas oscuras voces en off, sino que también Lucrecia queda bastante apartada de la acción, en la que se inmiscuía grotescamente si atendemos al original. El protagonismo de la escena se focaliza exclusivamente en la pareja protagonista. Lida critica esta omisión porque empobrece el personaje de Lucrecia: si bien conserva en escenas anteriores "la nota de sensata desconfianza", gracias a que Custodio, frente a otros adaptadores, posee una «intuición más exacta para asir la tónica de un personaje o de una escena", finalmente "ha reducido a esta sola nota el carácter de Lucrecia, pues ha desechado (...) tanto la explosión de sensual despecho como la solicitud por la honra de Melibea». En la versión a la que tuvo acceso Lida, por cierto, había una "apostilla» en boca de Lucrecia que Custodio eliminó en la versión de 1966, quizá atendiendo a la crítica afilada de la profesora: «la coletilla '¡ay de la pena!' introduce una inoportuna sugerencia de cante jondo» (Lida 1970: 657). 
En cuanto a la muerte de Calisto (129), que Custodio sitúa fuera de escena, las intervenciones de los criados son reducidas al mínimo. Custodio consideraba esta escena fundamentalmente antiheroica: «la muerte casual de Calisto un instante después de haber holgado con Melibea es una burla trágica del destino y una muestra más por el autor - expuesto por Pleberio- de que este mundo no pasa de ser un laberinto de errores. Calisto muere por consiguiente como un antihéroe, sin dignidad, como Celestina, Sempronio y Pármeno» (Custodio 1977: 481).

Una vez muerto Calisto, la acción se acelera ostensiblemente. La transición entre los primeros lamentos de Melibea, la aparición de Pleberio y el monólogo de Melibea son reducidos a sólo tres réplicas. Custodio no elimina solamente la referencia a ejemplos de la antigüedad, sino también el diálogo con el que Melibea trataba de ocultar a Pleberio la verdadera razón de su dolor y convencerle con pretextos falsos para subir a la azotea. En la versión de Custodio, Pleberio aparece sólo para escuchar el monólogo final de su hija y responder con el suyo. Hemos ganado en celeridad pero perdido en los sutiles argumentos que utiliza Melibea para conseguir su objetivo, lo cual estaba dotado de un patetismo de claro valor dramático (129-131). La prisa con la que Custodio resuelve esta parte final de la obra le impide discriminar adecuadamente los fragmentos de pura amplificación retórica de aquellos, muchos, que cumplen una función importante en el drama.

En cuanto al monólogo de Melibea, se hace patente aquí el acierto de haber eliminado a Alisa. La soledad del padre a la que Melibea hace referencia, también en el original, queda así reforzada. En cuanto a la selección del resto del texto, Custodio opta por mantener aquellos elementos que incumben a los tres personajes en juego (Calisto-Melibea-Pleberio) y no las consecuencias que la muerte de Calisto tiene en la ciudad (130). En coherencia con la eliminación del personaje de Alisa, el monólogo de Pleberio sucede inmediatamente al de Melibea, tras unas inútiles palabras, añadidas por Custodio, en las que trata de retener a su hija para que no se arroje al vacío:

\section{Pleberio: ¡No! ¡No! Hija mía, ¡Melibea! ¡Espera! ¡Hija mía! (131).}

Los cortes en el monólogo de Pleberio tratan quizá de darle un línea discursiva más clara: si «turbose la orden del morir» es porque el mundo ya no conserva el orden que Pleberio suponía en su juventud (132). La sucesión de poderes fatales que se atribuyen al amor es reducida al mínimo, decisión que es valorada positivamente por Earle: «Pleberio's lament, reduced to about five minutes' speaking time, is very effectively rendered" (Earle 1955: 50) y criticada por Lida: "El planto, despojado de ejemplos, se reduce a la queja contra Mundo y amor (...) También el planto de Pleberio revela una concepción más tradicional y austeramente hispáni- 
ca que la del modelo, ya que Custodio ha desechado las notas de dolor individual, peculiares de Rojas (...) que quizá inspiraron a Shakespeare (...) conservando en cambio las imágenes de Mena, Manrique, y sobre todo las de Petrarca (...) para realzar solemnemente el alcance universal de la lección» (Lida 1970: 487). Suponemos que, más que por fidelidad a unas tradiciones, Custodio decidió resumir el monólogo optando por una sola de las vías temáticas por las que éste discurre, y organizar todos sus elementos coherentemente en torno a una única segunda persona del singular, ya fuera referida al amor o al mundo, para evitar así una dispersión que pudiera resultar fatigosa para el público a estas alturas de la representación, con la acción principal ya resuelta. A pesar de la rigurosa reducción, no por coincidir con el final del original fue menos criticada la decisión de cerrar con el monólogo de Pleberio. Con respecto al estreno, Miguel Guardia dijo en México en la Cultura (229, 9 de agosto de 1953:2) que el final hubiera sido más eficaz si terminara con el suicidio de Melibea. De hecho, parece ser que en la representación de 1957 modificó el final en ese sentido (Maxwell 1971: 31), aunque finalmente lo recuperó en el texto de 1966 y en las posteriores representaciones de 1968 y 1978.

\section{Conclusiones}

Partiendo de una lectura muy personal, coherente en cualquier caso con su posición ideológica, la visión de la historia que había adquirido durante su vida y las circunstancias que le llevaron a aproximarse a La Celestina, Álvaro Custodio utiliza el teatro para entregar al público un clásico al que venera, y que se considera obligado a popularizar. Buen conocedor de los ritmos del espectador contemporáneo, conserva hábilmente aquello que la Tragicomedia tiene de relato eficaz, sorprendente y vivo, pero, en aras de la agilidad, recorta o transforma sin dudar muchos aspectos del original que sí tenían valor dramático. Especialmente interesante resulta la sutil conversión de Melibea en heroína romántica y de Pleberio en padre celoso al estilo del teatro del Siglo de Oro. El estudio de las sucesivas versiones, limitado porque en su mayoría sólo nos han llegado a través de testimonios indirectos, nos lleva a comprobar el afán de Custodio por mejorar y corregir constantemente su trabajo.

\section{Bibliografía}

Alborg, Juan Luis (1979), Historia de la literatura española, Madrid, Gredos, tomo I. 
Criado del Val, Manuel (1974), "Carta a Talavera», ABC, 27 de junio: 30. Custodio, Álvaro (1953), "La Celestina y la literatura estatal del Siglo de Oro", Cuadernos Americanos, CI, 4 (julio-agosto): 262-275.

- (1958), "Sobre el secreto de Melibea», Cuadernos Americanos, CI, 6 (noviembre-diciembre): 209-213.

- (1960), "Mi adaptación escénica de La Celestina», Excélsior (Diorama de la cultura), 14 de febrero: 2.

- (1966), "Proemio para el lector de esta adaptación teatral», en Rojas, F., La Celestina, Adaptación a la escena en tres actos de Álvaro Custodio, México, Ediciones Teatro Clásico de México: 15-38.

- (1969), Lope, Calderón y Shakespeare. Comparación de dos estilos dramáticos, México, Teatro Clásico de México.

- (1977), "La belleza actual de La Celestina», en CRIADO DE VAL, Manuel (Dir.), La Celestina y su contorno social. Actas del I Congreso Internacional sobre La Celestina (Madrid, 1974), Barcelona, Borrás: 471-483.

- (1979), "La Celestina como experiencia teatral», Celestinesca, 3, 1, Mayo: 33-38.

EArle, Peter G. (1955), "Four Stage Adaptations of La Celestina», Hispania, 38, 1: 46-51.

García Barrientos, José Luis (2001), Cómo se comenta una obra de teatro, Madrid, Síntesis.

Henríauez Ureña, Pedro (2001), Obra crítica, México, Fondo de Cultura Económica.

Heras González, Juan Pablo (2009), «La Barraca en México: Álvaro Custodio, Amparo Villegas y la Celestina», en Iñaki Beti Sáez y Mari Karmen Gil Fombellida, Exilio y Artes escénicas - Arte eszenikoak erbesten, San Sebastián, Saturraran: 235-251.

- (2012), La labor teatral de Álvaro Custodio, Tesis doctoral, Madrid, Universidad Complutense.

KisH, Kathleen (2007), "Celestina sale a las tablas en México», Actas del XV Congreso de la Asociación Internacional de Hispanistas "Las dos orillas", Monterrey, México, del 19 al 24 de julio de 2004, México, Fondo de Cultura Económica, vol. 1: 379-388.

Laborda, Ángel (1974), "Hacia un festival anual de La Celestina», ABC, 3 de julio: 89-90.

Lida De Malkiel, María Rosa (1970), La originalidad artística de La Celestina, Buenos Aires, Eudeba.

Mandel, A. S. (1978), "La Celestina revisited», Celestinesca, II, 2, Noviembre: 37-38.

MAXWell Dial, Eleanore (1971), "Spanish Classical Theatre in Mexico in the 1950's", Latin American Theatre Review (primavera): 29-38.

PONCE, Armando (1984), «Un breve retorno para el Cervantino. Álvaro Custodio: nada mejor en el teatro que los clásicos», Proceso, 20 de octubre: 47. 
Reyes de la Maza, Luis (1984), En el nombre de Dios hablo de teatros, México, UNAM, 1984.

RojAs, Fernando de (1966), La Celestina, Adaptación a la escena en tres actos de Álvaro Custodio, México, Ediciones Teatro Clásico de México.

Serrano Poncela, Segundo (1958), «El secreto de Melibea», Cuadernos Americanos, C, 5, Julio-Octubre: 488-510.

SeVErin, Dorothy S. (1997), «Introducción» a RojAS, Fernando de, La Celestina, Madrid, Cátedra.

Snow, Joseph T. (1997), "Un texto dramático no cerrado: notas sobre la Tragicomedia en el siglo XX», en BeLtrÁn, Rafael y CANET, José Luis, Cinco Siglos de Celestina: Aportaciones interpretativas, Valencia, Servei de Publicacions de la Universitat de València: 199-208. 



\section{Heras González, Juan Pablo, "La Celestina como emblema del exilio republicano en México: la versión de Álvaro Custodio», Celestinesca 37 (2013), pp. 49-86.}

\section{RESUMEN}

El director de escena Álvaro Custodio (1912-1992), miembro en su juventud de La Barraca de García Lorca, formó durante su exilio en México (1944-1973) una importante compañía dedicada a los clásicos del teatro español. El montaje más representativo de la compañía fue el de su particular versión de La Celestina, a la que acudió en primer lugar por identificar la heterodoxia de Fernando de Rojas con la de los republicanos españoles. El artículo analiza con detalle las motivaciones y las decisiones dramatúrgicas que conforman su versión, entre las que destacan, entre otras cosas, el perfilado de Melibea como heroína romántica y la atribución a Pleberio de rasgos propios del padre celoso de la comedia del Siglo de Oro.

palabras Clave: Celestina, Álvaro Custodio, exilio, representación teatral.

\section{ABSTRACT}

The stage director Álvaro Custodio (1912-1992), who belongs in his youth to García Lorca's La Barraca, created during his exile in Mexico (1944-1973) an important company dedicated to Spanish theatre classics. The most representative staging of his company was his own version of La Celestina, first identyfing Fernando de Rojas' heterodoxy with Spanish republicans. The article analyzes in detail causes and decisions in his version, as Melibea's profile as romantic heroine or identification of Pleberio with Golden Century comedy s jealous father.

KEY WORDS: Celestina, Álvaro Custodio, exile, theatrical performance.

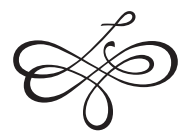

